\title{
Water footbath, automatic flushing, and disinfection to improve the health of bovine feet
}

\author{
T. Fjeldaas, ${ }^{* 1}$ M. Knappe-Poindecker, ${ }^{*}$ K. E. Bøe,† and R. B. Larssen ${ }^{\star}$ \\ ${ }^{*}$ Department of Production Animal Clinical Sciences, Norwegian University of Life Sciences, PO Box 8146 Dep, NO-0033 Oslo, Norway \\ †Department of Animal and Aquacultural Sciences, Norwegian University of Life Sciences, PO Box 5003, NO-1432 Ås, Norway
}

\begin{abstract}
Disinfecting footbaths are used to treat and prevent interdigital dermatitis (ID) and heel horn erosion (HHE). However, many disinfectants are disadvantageous for the environment and, as an alternative, washing of the feet has been introduced. Our aim was to investigate the effect of water footbaths (trial 1), footbaths with $\mathrm{CuSO}_{4}$ (trial 2), automatic water flushing (trial 3), and water flushing followed by disinfection with a glutaraldehyde-based compound (trial 4) in 4 randomized controlled clinical trials performed in a freestall dairy herd of approximately 45 Norwegian Red cows. At trimming before and after each trial, hind foot diseases, hardness of the claw horn (in D-units), locomotion, and cleanliness of the claws were recorded. Before each trial, the cows were divided in comparable study and control groups, based on prevalence of ID and HHE, parity, and days in milk. Using a transponder-regulated gate, the study groups were led through a footbath (trials 1 and 2) or an automatic washer (trials 3 and 4), whereas the control groups were left untreated. Each trial lasted $3 \mathrm{mo}$ and the curative effect in diseased cows and the preventive effect in cows with healthy feet on ID, HHE, and ID + HHE were analyzed. In trial 2, a preventive effect of $\mathrm{CuSO}_{4}$ on $\mathrm{HHE}$ compared with the untreated cows was observed. During trial 1, 100\% (11/11) of the treated cows with ID got better and $22 \%(2 / 9)$ without ID became diseased, whereas $92 \%(11 / 12)$ of the treated cows with ID + HHE got better and 38\% (3/8) without ID + HHE became diseased. During trial 2, 69\% (9/13) of the treated cows with ID got better and $11 \%(1 / 9)$ without ID became diseased. During trial 4, 19\% (3/16) of the untreated cows with ID + HHE got better and $71 \%(5 / 7)$ without ID + HHE became diseased. In trial 3 , no significant effects on ID, HHE, or ID + HHE were revealed. In trial $2\left(\mathrm{CuSO}_{4}\right)$, the treated cows' claw horn was harder after the trial compared with the controls (D-unit difference: 13.25). In trial 3 (stationary
\end{abstract}

Received September 27, 2013.

Accepted January 21, 2014.

${ }^{1}$ Corresponding author: terje.fjeldaas@nmbu.no water flushing) the treated cows' claw horn was softer after the trial when compared with the controls (D-unit difference: -15.66). The $\mathrm{CuSO}_{4}$ footbaths were useful to prevent HHE and indicate that automatic stationary flushing with only water had no beneficial effect on ID or HHE. The claw horn of cows walking through $\mathrm{CuSO}_{4}$ became harder and the claw horn of cows that had their hind feet flushed with water became softer compared with the controls.

Key words: bovine infectious foot disease, water footbath, disinfection, automatic flushing

\section{INTRODUCTION}

Infectious bovine foot diseases are increasing in many countries, causing pain and lameness, which is one of the most important welfare problems in dairy cattle (Galindo and Broom, 2002; Bruijnis et al., 2012). These diseases, including interdigital dermatitis (ID), heel horn erosion (HHE), digital dermatitis (DD), and interdigital phlegmon, also cause considerable economic losses (Sogstad et al., 2006; Bruijnis et al., 2010). Manure and urine damage claw horn and make it more vulnerable by causing keratin to swell (Berry, 2001; Gregory et al., 2006), and poor hygiene is an important predisposing factor for all infectious bovine foot diseases (Somers et al., 2005; Relun et al., 2013). The horn tissue absorbs water rapidly and claw horn hardness decreases with moisture content (Borderas et al., 2004).

Interdigital dermatitis and HHE are the most common infectious foot diseases in Norway (Sogstad et al., 2005; Knappe-Poindecker et al., 2013). Interdigital dermatitis has been associated with Dichelobacter nodosus (Laing and Egerton, 1978; Berry, 2001; KnappePoindecker et al., 2013), and a strong association exists between ID and HHE (Hultgren and Bergsten, 2001; Manske et al., 2002c), which also occurs mainly in wet, unhygienic environments. The pathogenesis of DD has been disputed, but studies have shown that Treponema spp. are important (Walker et al., 1995; Evans et al., 2008). Even though DD is seldom recorded in Norway, Treponema spp. have been detected frequently (Knappe-Poindecker et al., 2013). 
Disinfecting footbaths are routinely used to treat and prevent infectious foot diseases (Cook et al., 2012). The most frequently used disinfectants are $\mathrm{CuSO}_{4}$ and formaldehyde solutions, which both are known to reduce the prevalence of DD, ID, and HHE (Bergsten and Herlin, 1996; Manske et al., 2002a; Jorritsma et al., 2007). However, $\mathrm{CuSO}_{4}$ is disadvantageous for the environment and consequently has been abandoned in the European Union (Salam and El-Fadel, 2008). Formaldehyde has irritating effects on mucus membranes and also has carcinogenic effects on humans (Mitchell and Law, 1984; Collins and Lineker, 2004; IARC, 2006). In recent years, many new disinfecting agents have been developed and introduced. Most of them are compounds based on glutaraldehyde, quaternary ammonium, or organic and inorganic acids. Gregory et al. (2006) found that both formaldehyde and glutaraldehyde pretreatment reduced the sole-softening effects of urine on claws from slaughtered cows. Holzhauer et al. (2012) showed that acidified, ionized $2 \% \mathrm{CuSO}_{4}$ via a split leg footbath was significantly better at preventing new cases of DD over 4 mo than a standard formalinbased protocol. However, Thomsen et al. (2008) found no significant preventive or curative effect of $3 \mathrm{com}-$ mercial claw-care products based on glutaraldehyde, organic acids, and quaternary ammonium compounds compared with a negative control over an 8-wk period. Topical treatments with chlortetracycline or disinfectants are also frequently used and proved to reduce the prevalence of infectious foot diseases (Manske et al., 2002a; Greenough, 2007; Döpfer et al., 2011b).

Different methods of washing the claws in water have been introduced to improve claw hygiene without causing environmental disadvantage and health problems for cows or humans. However, the eventual beneficial effects are not adequately confirmed. Thomsen et al. (2012) performed a controlled trial washing the left side only and leaving the right side unwashed as a control when the cow passed through automatic water flushing. They showed that the flushing was able to clean the claws effectively. However, the odds of having DD were not significantly lower on the side being flushed with only water than on the control side of the cows.

Many of the new automatic claw-washing systems are combined with subsequent disinfection (Bertelsen, 2010). An advantage is that smaller volumes of disinfecting agents are needed than in traditional footbaths. Additionally, increasing contamination of the footbath by manure as more cows pass through is avoided. As far as we know, there is a lack of investigations of the effect of flushing with disinfectants compared with disinfection in traditional footbaths.

Long-term evaluations are required to test the efficacy of disinfecting footbaths, and individual cow factors are important for the differences between treatments (Döpfer et al., 2011a). Döpfer et al. (2011b) concluded that clinical, histopathological, and microbiological criteria are needed to evaluate the effect of topical treatments on the cure of acute DD. Despite huge efforts to reduce the incidence in recent years, infectious foot diseases are difficult to eliminate from a herd (Laven and Logue, 2006).

The aim of our study was to investigate and compare the effects of a water footbath (trial 1), traditional disinfectant footbath $\left(7 \% \mathrm{CuSO}_{4}\right.$; trial 2), stationary automatic water flushing (trial 3), and stationary automatic water flushing followed by disinfection with a glutaraldehyde-based compound (50\% Hoof Smart Bath; Ecolab Inc., Swindon, UK; trial 4) on ID and HHE, cleanliness of the claws, and physical properties of the claw horn.

\section{MATERIALS AND METHODS}

\section{Study Design and Population}

All 4 trials were performed as randomized controlled clinical studies with parallel group design. The trials were carried out in 1 freestall dairy herd with Norwegian Red cows from October 2010 to May 2012. The average herd size when the studies were performed was 44.7 cows, with an average yield of 8,349 $\mathrm{kg}$ of ECM per year, whereas the average for all Norwegian dairy herds was 23.6 cows and 7,440 $\mathrm{kg}$ of milk per year in 2012 . There were cubicles with mattresses (DeLaval M35R; DeLaval International AB, Tumba, Sweden) on the stall bases. The alley floors were covered with solid rubber (DeLaval M16; DeLaval International AB), which was scraped every $90 \mathrm{~min}$. All cows and heifers in the herd were let out to pasture May 10, 2011, and stayed out until September 25, 2011. This herd had been suffering from ID and HHE for approximately $10 \mathrm{yr}$ and in a study performed in the fall of 2007 and winter of 2008 , a mean prevalence of $32 \%$ ID and $72 \%$ HHE was recorded (Andersson and Hansen, 2008). In recent years, ID and HHE still have been frequently recorded. Spirochetes with the morphology of Treponema spp. had previously been identified from feet in the herd. Analyses of swabs and biopsies from the skin of the feet of some cows during the present trials identified $D$. nodosus by PCR and culturing and Treponema spp. by fluorescent in situ hybridization as described in Knappe-Poindecker et al. (2013).

\section{Study and Control Groups}

All cows and the heifers in the last 3 wk of gestation were included in the study and had claws trimmed 
before the start and at the end of each trial. After the initial trimming in trial 1 , all cows with ID, DD, and HHE were once treated topically with Intra Hoof-fit gel (Intracare BV, Veghel, the Netherlands) on request from the farmer. No topical treatment was performed later during the 4 trials.

After the initial examination at the start of trial 1, the cows were listed by claw health status (ID, HHE, or healthy), parity, and DIM at day of trimming. Every second cow on the list was allocated to the study group (A) and the others to the control group (B) to make the prevalence of ID and HHE approximately equal at the start of trial 1.

For the allocation to groups in trial 2, the treated cows from group A and the untreated cows from group $\mathrm{B}$ were listed separately as described above. Every second cow on both lists was allocated to the study group $(\mathrm{A} 1+\mathrm{B} 1)$, and the others to the control group (A2 $+\mathrm{B} 2$ ). The allocation of cows to groups in trial 2 is illustrated in Figure 1. The allocation was performed identically in trials 3 and 4 . Cows that were sold or culled during a trial were excluded from the study and for the ordinal variables, only cows trimmed and diagnosed both before and after each trial were included in the study sample.

\section{Study Treatments}

The study treatments for all 4 trials are presented in Table 1. By 2 already-existing alleyways from the milking parlor and guided by an automatic transponderregulated gate, all cows in the study groups were led through a footbath (trials 1 and 2) or through automatic flushing (trials 3 and 4) after milking twice per day for $3 \mathrm{mo}$, whereas the cows in the control groups were led outside and left untreated (Figure 2). The footbath (DeLaval automatic) was $233 \mathrm{~cm}$ long, 74 $\mathrm{cm}$ wide, and 17 to $22 \mathrm{~cm}$ deep. In trial 1, the water footbath that the study group (A) walked through was cleaned and filled with tap water before every milking. In trial 2, the study group $(\mathrm{A} 1+\mathrm{B} 1)$ walked through $7 \% \mathrm{CuSO}_{4}$ every second week and the $\mathrm{CuSO}_{4}$ solution was changed every third day. In trial 3 , the hind feet of

Trial 1

\begin{tabular}{|c|c|c|}
\hline $\begin{array}{c}\text { A } \\
\text { Water }\end{array}$ & A1 & $\begin{array}{c}\mathrm{A} 1+\mathrm{B} 1 \\
\mathrm{CuSO}_{4}\end{array}$ \\
\hline B & B1 & $\mathrm{A} 2+\mathrm{B} 2$ \\
\hline Control & B2 & Control \\
\hline
\end{tabular}

Figure 1. The allocation of cows into comparable study and control groups in trial 2. all the cows in the study group $(\mathrm{C})$ were automatically flushed with water from 2 nozzles for $6 \mathrm{~s}$ with 0.8 to 1.0 L (pressure: $700 \mathrm{kPa}$ ) while the cows stood in a Bovibooster automatic flushing system (Heinagergaard I/S, Give, Denmark). The flushing was interrupted for 10 d (December 23, 2011, to January 2, 2012) because of an outbreak of pseudocowpox. In trial 4 , the automatic water flushing of the study group $(\mathrm{C} 1+\mathrm{D} 1)$ described above was followed by disinfection. The active biocidal component was glutaraldehyde (70 g/L of liquid) combined with polymeric aluminum salts in a solution with pH 3.0 to 3.4 (50\% Hoof Smart Bath; Ecolab Inc.).

\section{Recording of Data}

At the Start and at the End of all 4 Trials. The locomotion score (LocS) of all cows was recorded on a scale from 1 to 5 before claw trimming, where LocS = 1 was defined as standing and walking with a straight back and LocS $=5$ as standing and walking with an arched back with limited weight bearing on one or more limbs (Sprecher et al., 1997). Furthermore, the cleanliness of the right hind claws was recorded as clean (1), minimally dirty (2), moderately dirty (3), or very dirty (4), according to Knappe-Poindecker et al. (2013). The abaxial claw wall and the plantar aspect of the foot were assessed when the foot was on the ground, and the interdigital space was assessed directly after the foot had been elevated in the chute. When the 3 scores were summarized, a total cleanliness score of the claws of minimum 3 and maximum 12 was created.

The claw trimming was performed by a certified claw trimmer. After trimming, the hardness of the claw horn was measured and recorded by the second author. Using a Shore durometer (Bareiss Hardness Tester HP-D; Heinrich Bareiss Prüfgerätebau GmbH, Germany), the hardness of the right lateral hind claw was measured in D-units directly after correct trimming on 4 defined points, which are illustrated in Figure 3 (Borderas et al., 2004).

The hind claws were examined and diagnosed for infectious foot diseases by the first and second authors. Interdigital dermatitis is still much more prevalent than DD in Norway (Knappe-Poindecker et al., 2013) and in agreement with the Norwegian Dairy Herd Recording System, ID and DD were recorded together as dermatitis (Fjeldaas et al., 2011). Dermatitis and HHE were graded and recorded as not present (0), mild (1), moderate (2), or severe (3; Sogstad et al., 2005), and the highest score on each cow was recorded. Definitions are found in Table 2. Dermatitis score 1 and 2 were equal to ID, and a dermatitis score of 3 was equal to DD (Knappe-Poindecker et al. 2013). All DD lesions diagnosed in this study were M1 (early stage of DD 


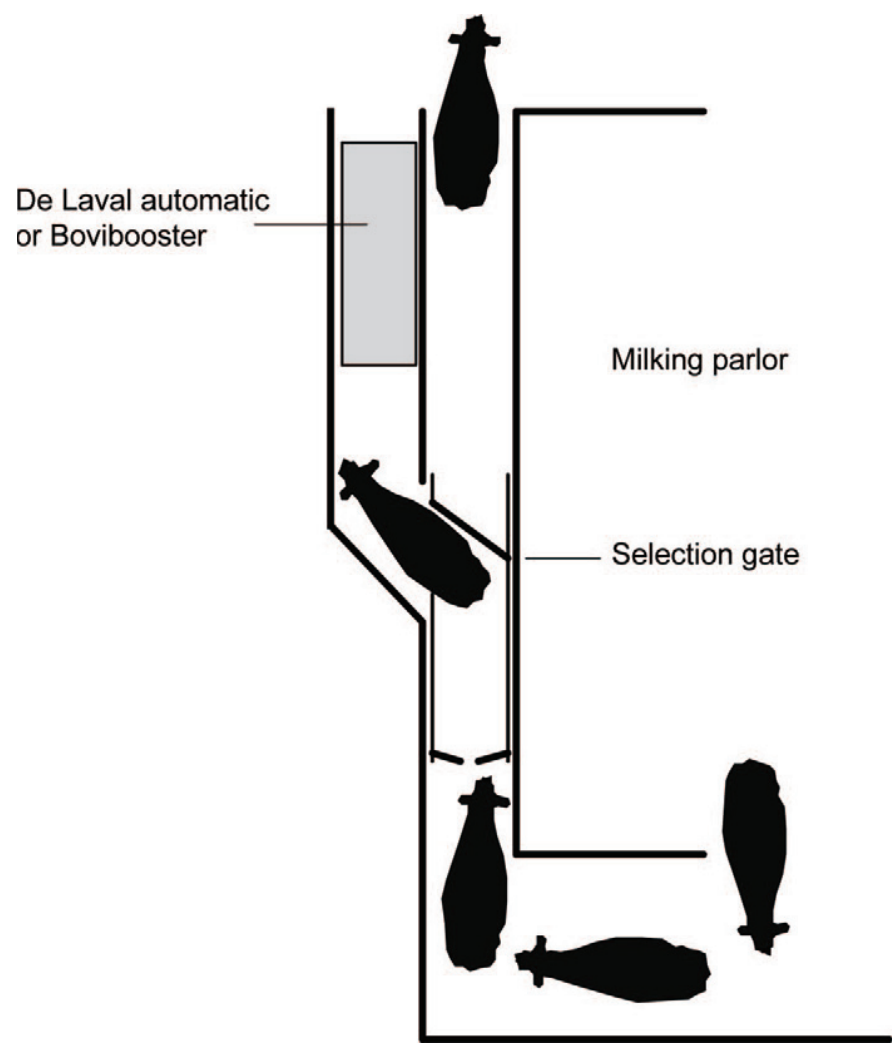

Figure 2. The transponder-regulated gate (DeLaval International $\mathrm{AB}$, Tumba, Sweden) and the location of the DeLaval automatic footbath and Bovibooster automatic flushing system (Heinagergaard I/S, Give, Denmark). The gate led the cows in the study groups to the left through the footbath (trials 1 and 2) or the automatic flushing system (trials 3 and 4 ) and the cows in the control groups were led straight ahead without any treatment.

with a circumscribed granulomatous area $0.5-4 \mathrm{~cm}$ in diameter; Döpfer et al., 1997).

Additional Recordings and Observations in the Different Trials. In trial 1, the length of the dorsal wall of the right lateral hind claw was measured with a slide gauge from the coronary band along the dorsal border to the apex of the claw. After the initial trimming on October 19, 2010, a mark was cut on the dorsal edge $3.5 \mathrm{~cm}$ proximal to the apex of the claw (L1). Afterward, the length from the mark to the coronary band (L2) was measured and recorded. To determine the growth and wear of the claw during trial 1, the lengths from the mark to the coronary band (L2) and to the cranial tip of the claw (L1) were measured before trimming at the end of the trial. In trial 2, the length from the coronary band to the previously described mark on the dorsal edge of the claw (L2) was measured before trimming to determine the growth of the claw horn.

The cows were also observed on 2 occasions by the second author during trial 1 when they were passing

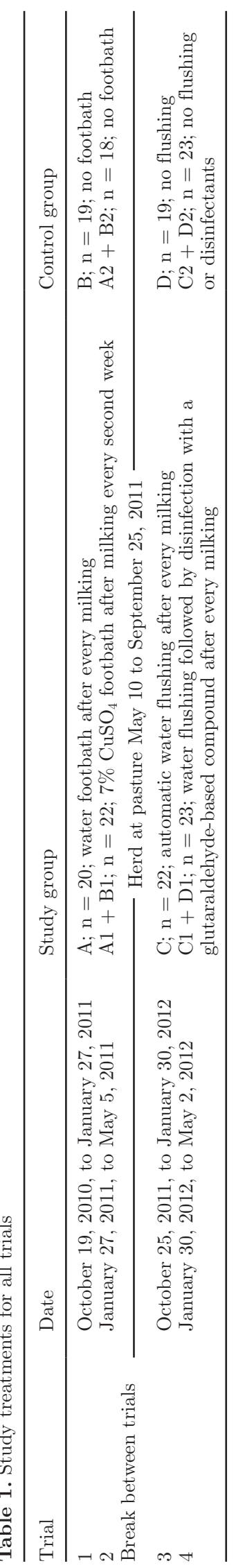


Table 2. Definition of foot lesions recorded at claw trimming

\begin{tabular}{lcl}
\hline Lesion & Score & Definition \\
\hline Dermatitis (D) & 1 & Superficial, hyperemic, slightly exudative lesion of the digital skin or interdigital skin, or both \\
& 2 & (interdigital dermatitis) \\
& 3 & Exudative lesion with thickening of the skin (interdigital dermatitis) \\
Heel horn erosion (HHE) & 1 & Slight defects of the horn integrity, pits, and small fissures \\
& 2 & V-shaped fissures or craters of the heel bulb not affecting the corium \\
& 3 & V-shaped profound fissures or craters affecting the corium of the heel and bulb \\
\hline
\end{tabular}

through the water footbath and the number of cows defecating in the water was recorded. Afterward, the content of the footbath was stirred and the samples were analyzed for sedimentable solids and dry substance.

During trial 4, the farmer discovered that some of the cows avoided being flushed by placing their hind feet behind the nozzles, and video monitoring was installed to identify these cows. The monitoring was performed after 22 subsequent milkings, starting April 14 and finishing April 24, 2012. Two video cameras were used. One camera focused on the head of the cows to identify each of them by their ear marking. The second camera focused on the hind claws and the automatic water flushing to identify the position of the feet.

\section{Data Handling and Statistical Analyses}

After recording the data in Excel 2010 software (Microsoft Corp., Redmond, WA) new variables were created as sums of other variables [e.g., the overall hardness was calculated as the sum of the measured hardnesses of the 4 location-specific recordings (H1 + $\mathrm{H} 2+\mathrm{H} 3+\mathrm{H} 4)]$. Likewise, a new variable for infectious diseases (ID + HHE) was created as the sum of the ID (also including 3 recordings of DD in trial 1)
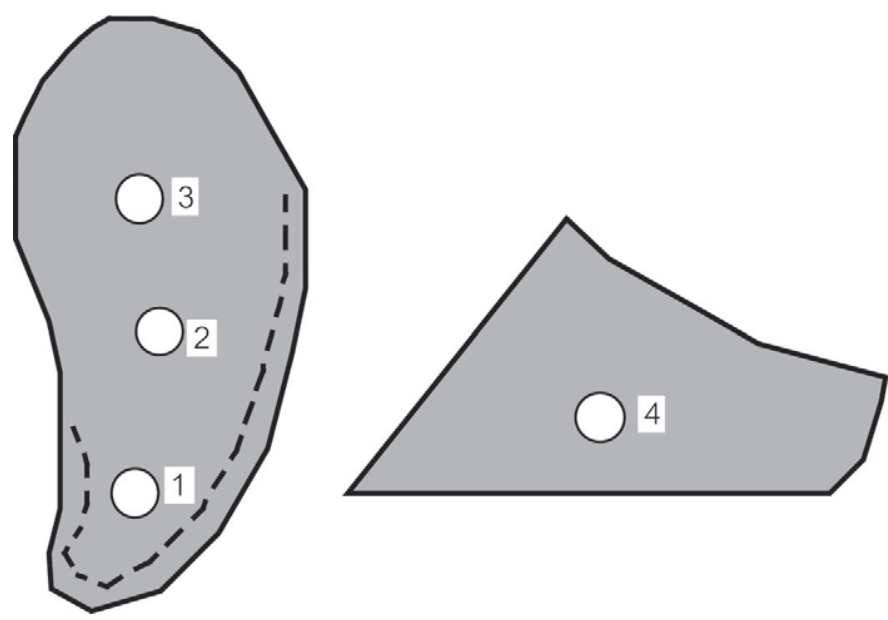

Figure 3. Hardness measuring points on the hind claws. and HHE variables, which are proven to be interrelated (Hultgren and Bergsten, 2001; Knappe-Poindecker et al., 2013). Also new variables were created that coded for the change in recorded variables from the start to end of each trial. For the ordinal variables ID, HHE, and ID + HHE the change variables were coded as binomial variables, where 1 versus 0 coded for improvement among diseased (including both cows with a reduction in lesion score and cows that were cured) and for becoming diseased among cows not having the diseases. For quantitative variables and for other ordinal variables with many levels (e.g., the overall hardness at all points), the change was coded as start level - stop level (i.e., reduction denoted as negative values of the change variables).

The statistical null hypotheses tested were (1) the risk of becoming diseased among healthy cows would be equal to the risk of becoming better among diseased cows, tested separately both in the study and in control groups, (2) the risk of improvement among the diseased cows would be equal in the study and control groups, and (3) the risk of becoming diseased among healthy cows would be equal in the study and control groups. Thus, all $P$-values were based on 2 -sided testing with a $5 \%$ significance level and a $95 \%$ level for the confidence intervals.

For the ordinal variables ID, HHE, and ID + HHE, an exact $95 \%$ confidence interval based on binomial distribution was calculated for both the proportions of diseased cows improving (i.e., lower score at the end than at the start), as well as the proportion of healthy cows not becoming diseased. A comparison of curative as well as preventive effects between both study and control groups was done using Fisher's exact test. Within both the study and control groups, the proportion improving (i.e., curative effect) was compared with the proportion of not becoming diseased (i.e., preventive effect) using Fisher's exact test. Calculations were performed using STATA 12.1 (StataCorp LP, College Station, TX).

Continuous variables including the overall hardness $(\mathrm{H} 1+\mathrm{H} 2+\mathrm{H} 3+\mathrm{H} 4)$ that had D-unit (claw horn hardness) values ranging from 104 to 196 were analyzed based on Student's $t$-test (ANOVA) and $95 \%$ confidence 
intervals of means and comparison between the study and control groups were done accordingly. Calculations were performed using JMP 10 software (SAS Institute Inc., Cary, NC).

\section{RESULTS}

\section{Claw Length, Hardness of the Claw Horn, and Cleanliness of the Claw}

In trial 1, the mean growth rate was $4.2 \mathrm{~mm}$ (95\% CI: 3.6 to $4.7 \mathrm{~mm}$ ) per month in the study group versus 4.3 $\mathrm{mm}$ (CI: 3.8 to $4.8 \mathrm{~mm}$ ) in the control group. The mean wear rate was $2.4 \mathrm{~mm}$ (CI: 1.8 to $2.9 \mathrm{~mm}$ ) per month in the study group and $2.2 \mathrm{~mm}$ (CI: 1.7 to $2.7 \mathrm{~mm}$ ) in the control group. In trial 2 , the mean growth rate in both study and control groups was $4.6 \mathrm{~mm}$ (CI: 4.0 to $5.3 \mathrm{~mm}$ ) per month.

The results from the analyses of the overall hardness of the claw horn on the 4 defined points (H1-H4) are given in Table 3. In trial 2 with $\mathrm{CuSO}_{4}$, a tendency was observed toward harder claw horn on all single points after versus before the trial compared with the controls, but only the claw wall (H4) was significantly harder (Dunit difference: 7.88 ; $95 \%$ CI: 0.14 to $15.61 ; P=0.046$ ). In trial 3 with stationary water flushing, a tendency was observed toward softer claw horn on all single points after versus before the trial compared with the controls, but only the claw wall (H4) was significantly softer (D-unit difference: -9.44 ; CI: -17.77 to -1.11 ; $P=0.027)$.

No significant differences in total cleanliness score of the claws were revealed between the study and control groups in any of the 4 trials [trial 1: 0.42 (CI: -0.19 to 1.04); trial 2: -0.31 (CI: -0.87 to 0.26 ); trial 3: 0.06 (CI: -0.52 to 0.65 ); trial 4: 0.05 (CI: -0.34 to 0.46$)$ ].

\section{Infectious Foot Diseases}

The prevalence of different scores of ID and HHE are shown in Table 4, and the analyses of healthy cows and cows with ID, HHE, and ID + HHE after versus before all trials within and between the study and control groups are in Table 5. In trial 2, a preventive effect of $\mathrm{CuSO}_{4}$ on $\mathrm{HHE}$ was detected compared with the untreated cows. During trial 1, 100\% (11/11) of treated cows with ID got better and $22 \%(2 / 9)$ of treated cows without ID became diseased, whereas $92 \%(11 / 12)$ of treated cows with ID + HHE got better and 38\% (3/8) of treated cows without ID + HHE became diseased. During trial 2, 69\% (9/13) of treated cows with ID got better and $11 \%(1 / 9)$ of treated cows without ID became diseased. During trial 4, 19\% (3/16) of untreated cows with ID + HHE got better and $71 \%(5 / 7)$ of untreated cows without ID + HHE became diseased.

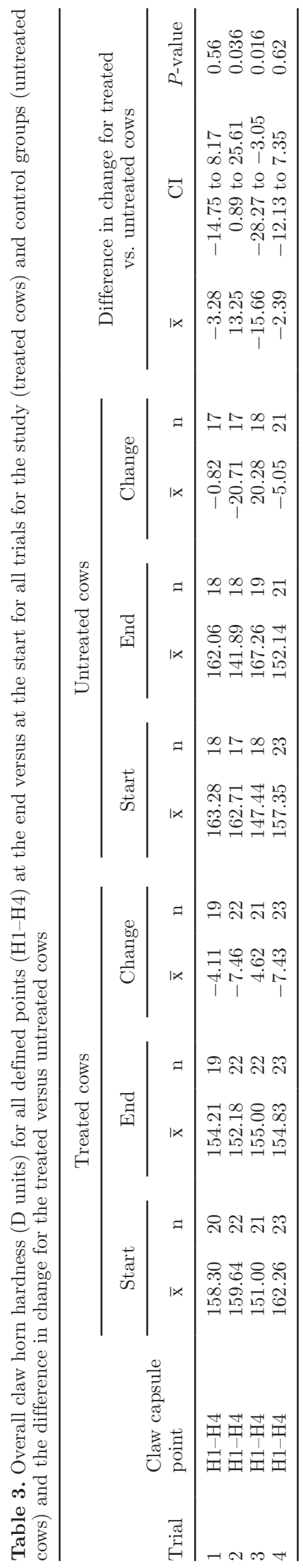




\section{Locomotion}

The mean LocS in the study and control groups before and after all trials ranged from 1.27 to 1.53 and from 1.15 to 1.61 , respectively. No significant differences in LocS were revealed after versus before within or between the study and control groups in any of the 4 trials.

\section{Additional Observations}

Trial 1: Manure in the Water Footbath. Observation of the cows at 2 morning milkings (middle and last during trial 1) revealed that none at all or only 1 cow defecated in the water footbath at these milkings. Analyses of the content of the footbath showed $16.3 \mathrm{~mL}$ of sedimentable solids/L and $0.89 \mathrm{~g}$ of dry substance/L

Table 4. Prevalence (n) of different scores of interdigital dermatitis (ID), digital dermatitis (DD), and different scores of heel horn erosion (HHE) for the study and control groups before and after all 4 trials

\begin{tabular}{|c|c|c|c|c|}
\hline \multirow[b]{2}{*}{ Score } & \multicolumn{2}{|c|}{ Study group } & \multicolumn{2}{|c|}{ Control group } \\
\hline & Before trial & After 3 mo & Before trial & After 3 mo \\
\hline & \multicolumn{4}{|c|}{ Trial 1} \\
\hline & \multicolumn{2}{|c|}{ Group A $(\mathrm{n}=20)$} & \multicolumn{2}{|c|}{ Group B (n = 19) } \\
\hline ID score 0 & 9 & 16 & 9 & 6 \\
\hline ID score 1 & 6 & 3 & 5 & 11 \\
\hline ID score 2 & 3 & 1 & 4 & 2 \\
\hline $\mathrm{DD}$ & 2 & 0 & 1 & 0 \\
\hline HHE score 0 & 18 & 16 & 18 & 17 \\
\hline HHE score 1 & 2 & 3 & 0 & 1 \\
\hline HHE score 2 & 0 & 1 & 1 & 1 \\
\hline \multirow[t]{3}{*}{ HHE score 3} & 0 & 0 & 0 & 0 \\
\hline & \multicolumn{4}{|c|}{ Trial 2} \\
\hline & \multicolumn{2}{|c|}{ Group A1 + B1 $(\mathrm{n}=22)$} & \multicolumn{2}{|c|}{ Group A2 + B2 (n=18) } \\
\hline ID score 0 & 9 & 16 & 9 & 12 \\
\hline ID score 1 & 11 & 6 & 7 & 4 \\
\hline ID score 2 & 2 & 0 & 2 & 2 \\
\hline $\mathrm{DD}$ & 0 & 0 & 0 & 0 \\
\hline HHE score 0 & 21 & 20 & 13 & 9 \\
\hline HHE score 1 & 1 & 1 & 3 & 5 \\
\hline HHE score 2 & 0 & 1 & 2 & 4 \\
\hline \multirow[t]{3}{*}{ HHE score 3} & 0 & 0 & 0 & 0 \\
\hline & \multicolumn{4}{|c|}{ Trial 3} \\
\hline & \multicolumn{2}{|c|}{ Group C (n = 22) } & \multicolumn{2}{|c|}{ Group D (n = 19) } \\
\hline ID score 0 & 7 & 7 & 4 & 7 \\
\hline ID score 1 & 15 & 14 & 13 & 11 \\
\hline ID score 2 & 0 & 1 & 2 & 1 \\
\hline $\mathrm{DD}$ & 0 & 0 & 0 & 0 \\
\hline HHE score 0 & 18 & 15 & 16 & 14 \\
\hline HHE score 1 & 4 & 7 & 3 & 3 \\
\hline HHE score 2 & 0 & 0 & 0 & 2 \\
\hline \multirow[t]{3}{*}{ HHE score 3} & 0 & 0 & 0 & 0 \\
\hline & \multicolumn{4}{|c|}{ Trial 4} \\
\hline & \multicolumn{2}{|c|}{ Group C1 + D1 (n=23) } & \multicolumn{2}{|c|}{ Group C2 + D2 (n = 23) } \\
\hline ID score 0 & 8 & 13 & 11 & 15 \\
\hline ID score 1 & 13 & 8 & 12 & 6 \\
\hline ID score 2 & 2 & 2 & 0 & 2 \\
\hline DD & 0 & 0 & 0 & 0 \\
\hline HHE score 0 & 19 & 13 & 16 & 10 \\
\hline HHE score 1 & 4 & 7 & 5 & 7 \\
\hline HHE score 2 & 0 & 3 & 2 & 5 \\
\hline HHE score 3 & 0 & 0 & 0 & 1 \\
\hline
\end{tabular}


when no cows had defecated in the footbath versus $26.3 \mathrm{~mL}$ of sedimentable solids/L and $1.8 \mathrm{~g}$ of dry substance/L when 1 cow had defecated.

Trial 4: Video Monitoring for 11 d. The video monitoring after 22 subsequent milkings revealed that the 24 treated cows were standing correctly in the automatic claw washer at $341(69 \%)$ of the altogether 496 passages. At 49 (10\%) of the passages they were standing with their hind feet too narrow to be properly flushed, and at $37(7 \%)$ of the passages with one hind foot and at $69(14 \%)$ of the passages with both hind feet behind the automatic flushing nozzles. Four cows frequently (at $\geq 8$ monitored passages) placed their hind feet behind the nozzles. No cows lifted their hind feet during the flushing.

\section{DISCUSSION}

\section{General Considerations of the Study Design}

Many studies of disinfecting footbaths (Laven and Logue, 2006; Holzhauer et al., 2012) and a few of automatic flushing have been published (Nielsen et al., 2012; Thomsen et al., 2012; Fiedler et al., 2013), but they are difficult to compare because of differences in design, duration of the studies, and choice of disinfecting agents. Our study design has, as far as we know, not been used for a footbath study before. Compared with trials performed in split footbaths, our design has the advantage that both the right and left side of the cow were treated the same way. The risk for transferring the infection from one treated foot to the untreated contralateral one was reduced. However, a disadvantage versus a split bath design was that individual differences between the cows in the study and control groups could have biased our results.

Both our traditional footbath and split footbaths required that the study and control feet were walking in the same alleys. This implies that the infectious agents possibly could be spread from the untreated to the treated feet. Oppositely, when half of the feet in the herd were treated, the infectious pressure in the whole herd was reduced and could cause a decreased prevalence of infectious foot diseases in the control feet.

We aimed to reduce the influence of treatments between the trials by performing the 2 trials with only water (trials 1 and 3) before the 2 trials with disinfection (trials 2 and 4). The effect of $\mathrm{CuSO}_{4}$ used in trial 2 was probably reduced to a marginal level before the start of trial 3 after grazing on pastures for $>4$ mo during the summer. Finally, regrouping of the study and control groups between trials 1 and 2, and between trials 3 and 4 made the new groups comparable, regardless of the previous trial. The cows with ID, DD, 
and HHE were treated topically with Intra Hoof-fit gel before trial 1 , but because they were equally divided in the study and control groups, they were comparable. However, this gel is proven to be effective for the treatment of M2 ("classical" ulceration of DD up to $7 \mathrm{~cm}$ in diameter) lesions of DD (Holzhauer et al., 2011) and we cannot exclude that the treatment may have reduced the prevalence in both groups.

Previous footbath studies have lasted for various lengths of time (Laven and Hunt, 2002; Manske et al., 2002a; Cook et al., 2012). Döpfer et al. (2011a) recommended that trials, which test the effect of footbaths on bovine foot health, should last at least 3 mo to produce reliable results. Our study was designed to fulfill this demand, even though trial 3 was interrupted for a period of $10 \mathrm{~d}$ because of disease and consequently lasted for only $80 \mathrm{~d}$.

\section{Statistical Analysis}

The idea behind the chosen method for statistical testing was that to be of any use the curative effect should be at least as big at the risk of becoming diseased, and that a possible positive effect of treatment should be detected by comparison of treated cows versus controls within the diseased, and that a possible preventive effect should be detected by comparison of treated cows versus controls within the healthy ones. The $P$-values are based on 2-sided hypothesis testing. Thus, the testing is conservative, as could be argued for the use of 1-sided testing in this situation. Even more so, because in the effects that showed up as significant, the direction of the effect was consistent in the testing of all 3 hypotheses. The small group sizes reduced the powers for testing the hypotheses in the study, in particular for the grouping variables.

\section{Claw Length, Hardness of the Claw Horn, and Cleanliness of the Claw}

The growth and wear rates in both the study and the control groups in trial 1 and the growth rates in trial 2 were higher than those Telezhenko et al. (2009) found on solid rubber flooring with short contact with asphalt flooring. No differences in growth or wear between the study and control group in trial 1 may partly agree with no difference in claw horn hardness between the treated and untreated cows.

Gregory et al. (2006) showed that rainwater softened the sole of claws from slaughtered cows. In the current study, softening of the claw horn by water flushing in trial 3 but not by the water footbath in trial 1 indicates that the flushing itself influenced the hardness. The softening of the abaxial wall of the claw, which is the hardest part of the claw capsule, in trial 3, may have influenced the wear of the horn and also the risk for damage and infection. The reason for significantly softer horn only on the claw wall in the treated cows versus the controls was probably that the wall, in contrast to the sole, was not trimmed before the hardness was measured. A tendency toward softer horn also at the other 3 points in the treated versus the untreated cows indicates that the entire claw horn capsule had become softer after stationary automatic flushing with water.

Increased hardness on the claw wall and when all 4 points of the claw capsule were added together in the study group in trial 2 compared with the controls was expected and agrees with the astringent effect of $\mathrm{CuSO}_{4}$ (Trent and Redic-Kill, 1997).

Observation of passages showed that most cows did not defecate in the footbath, and analyses of the contents of the footbath confirmed that manure was washed off the claws during the passage. No significant difference in claw cleanliness was, however, revealed between the study and control groups in any of the 4 trials. Fiedler et al. (2013) performed a similar study and could only detect differences in cow cleanliness between study and control groups when evaluated directly after washing. This difference was not present when the cows returned to the stall for minutes or hours before having the cleanliness evaluated. In the present study, the visual effect of the footbath or flushing on the cleanliness probably was relatively short after the cows returned to the stall. In addition there was a waiting area to ensure efficacy directly before the trimming chute where several cows defecated while waiting. Even though the manure was regularly removed, it could possibly lead to further contamination of the claws directly before entering the chute and the recording of claw cleanliness.

\section{Infectious Foot Diseases}

Trial 1-Footbath with Water. An important aim in trial 1 was to investigate how water and improved hygiene alone could influence the diseases. The overall beneficial effect on ID only in the study group (A) during trial 1 , however, not being significant compared with the control group (B), partly agrees with Speijers et al. (2010), who found that tap water alternating with $5 \% \mathrm{CuSO}_{4}$ led to an absence of DD M2 lesions compared with $5 \% \mathrm{CuSO}_{4}$ and salt water alternating with $5 \% \mathrm{CuSO}_{4}$. Walking through water twice daily may have reduced the bacterial pressure on the skin by removing or diluting manure and urine.

Footbaths filled with clean water twice daily will probably never be routinely used, partly because the large amount of water usually needed is not available or too expensive. The disposal of the water with the 
manure also caused practical problems in our study herd. Footbaths with water are, however, often recommended as prewash baths in 2-bath solutions where the cows afterward walk through a disinfecting footbath. Soap can be added to the water footbath to achieve better cleaning and several such commercial products are available. A 2-bath solution does, however, require more than twice the floor space than one disinfecting footbath and disposal of the large volumes of water may create difficulties. Cows tend to become slightly apprehensive when entering the prewash bath and this may lead to increased defecation and contamination by the time they reach the second bath containing the active chemical (Blowey and Chesterton, 2012; Cook et al., 2012).

The footbath used in our study was $2 \mathrm{~m}$ long, which is a common size for footbaths in Norway. However, a recent study found that the frequency of foot immersions was influenced by both footbath length and stepin height, and they concluded that the optimal size and design considering both efficacy and a minimum use of disinfectants should be 3 to $3.7 \mathrm{~m}$ long and 0.5 to $0.6 \mathrm{~m}$ wide (sloping walls) with a $28-\mathrm{cm}$ step-in height (Cook et al., 2012). Our footbath was shorter and, consequently, each cow took fewer steps in the water or disinfectant solution than recommended in their study. The only way to use a footbath of the recommended size in Norway today is to cast one in concrete or import one. The length of our footbath was realistic in view of the situation in Norwegian dairy cattle herds.

Trial 2-Footbath with $7 \% \mathrm{CuSO}_{4}$. A footbath with $\mathrm{CuSO}_{4}$ was chosen for trial 2 because this disinfectant has been proven to reduce the lesion scores of $\mathrm{DD}$ and the prevalence of ID and HHE (Bergsten and Herlin, 1996; Laven and Hunt, 2002; Jorritsma et al., 2007). Cook et al. (2012) found that the median herd in 65 freestall herds in 5 different countries was treated with a footbath twice per day for $3 \mathrm{~d}$ per week and that $\mathrm{CuSO}_{4}$ was the most commonly used agent. The preventive effect of walking through $7 \% \mathrm{CuSO}_{4}$ twice daily every second week on HHE in trial 2 was expected and agrees with Bergsten et al. (2007), but is partly in contrast to Manske et al. (2002a) who found that a footbath with $\mathrm{CuSO}_{4}$ had a curative but no significant preventive effect regarding DD associated with severe HHE. The small group sizes may explain why we found no significant curative effect on HHE, but may also be a seasonal effect of housing for several months. Several previous studies have documented a higher prevalence and increased severity of HHE in the spring compared with autumn (Andersson and Lundström, 1981; Manske et al., 2002b). Copper sulfate may also have been distributed both in the alleys and in the cubicles, resulting in a reduced bacteriological pressure on all the cows, with reduction of the difference between the study and control groups.

The disposal of $\mathrm{CuSO}_{4}$ will cause environmental problems and could have long-term toxic effects on human health (Salam and El-Fadel, 2008). Copper sulfate has been abandoned in the European Union and its use is also restricted in Norway by legislation regarding pollution (Norwegian Ministry of the Environment, 1981).

Trial 3-Stationary Automatic Flushing with Water. Trial 3 were included in our study because automatic flushing requires smaller volumes of water than footbaths. No reduction of ID or HHE in trial 3 when flushed with water partly agrees with previous studies (Nielsen et al., 2012; Thomsen et al. 2012). Both of those studies found a slight, but not significant improvement of DD when cows walked through a split bath and got their left claws automatically washed with the right side as a control. However, Thomsen et al. (2012) found a positive effect of tap water washing with $0.4 \%$ soap on DD.

The front feet were not directly flushed in the present study, consequently causing bacteriological pressure on the hind feet. Flushing the feet while the cows are walking, as Thomsen et al. (2012) did, may result in better washing of the interdigital space. In our study, the flushing pressure was slightly lower than recommended (800 to $1,100 \mathrm{kPa}$ ). This and also the 10 -d interruption caused by the pseudocowpox outbreak may have influenced our results.

The monitoring during trial 4 showed that some of the cows avoided the flushing repeatedly and this probably also happened to some extent during trial 3. By installing the stationary flushing system in the milking robot, a more controlled and correct position of the feet during flushing could be achieved. Arguments are, however, raised that such a location may imply negative consequences for the health of the udder and the quality of the milk.

Trial 4-Stationary Automatic Flushing with Water Followed by Disinfection with a Glutaraldehyde-Based Compound. No effect on ID or HHE in the treated versus the untreated cows in trial 4 partly agrees with Thomsen et al. (2008), who did not find differences with respect to DD in a split footbath trial between the treated right claws and the left control claws for glutaraldehyde where all the cows walked through the footbath twice daily for $2 \mathrm{~d}$ per week for 8 wk. However, the overall negative effect on ID + HHE only in the control group (C2 + D2) during trial 4 may indicate a slight preventive effect in the study group $(\mathrm{C} 1+\mathrm{D} 1)$, but the difference between the 2 groups was not significant.

The effect of this glutaraldehyde-based compound used for flushing has not been tested previously. Foot- 
baths with 3 to $5 \%$ glutaraldehyde are frequently used to control infectious foot diseases because glutaraldehyde is favorable compared with $\mathrm{CuSO}_{4}$ with respect to the environment and legislation places no restrictions on its use or disposal. However, the effect is sparsely documented and Laven and Logue (2006) found that the effect of glutaraldehyde for treatment of DD was not significantly different from hoof trimming alone. Also in trial 4, only the plantar part of the hind claws was directly flushed. The effect would probably have been better if all cows in the herd had been flushed with the glutaraldehyde compound. The location of the automatic washer after the milking parlor delayed the walking speed of the cows and the milking, and frequent incorrect positioning of the hind claws was obviously a disadvantage.

\section{Locomotion}

Even though the present herd had been suffering from ID and HHE for many years, there had been few lame cows. Interdigital dermatitis and HHE usually do not cause lameness and the low LocS were as expected and in agreement with Knappe-Poindecker et al. (2013). The low prevalence of lameness in the present study herd probably made it difficult to discover differences within or between the study and control groups.

\section{CONCLUSIONS}

The present study shows that $\mathrm{CuSO}_{4}$ footbaths had a preventive effect on HHE. Stationary automatic flushing of the hind feet with only water had no beneficial effect on ID or HHE. The claw horn of cows walking through a $\mathrm{CuSO}_{4}$ footbath became harder and that of cows that had their hind feet automatically flushed with water became softer compared with the controls.

\section{ACKNOWLEDGMENTS}

The authors thank farmer Ivar Andreassen (Horten, Norway) and his family for all their contributions over more than 2 yr. We also thank claw trimmer Ole Barup and his assistant Almantas Jonkus, Atle Haanshuus from DeLaval International AB (Tumba, Sweden) for the loan of the transponder-regulated gate, Fjøssystemer A/S (Fåvang, Norway), and Henrik Hein Jørgensen (Heinagergaard I/S, Give, Denmark) for their support with the Bovibooster, and Svein Nilsen at Ecolab Inc. (Swindon, UK) for delivering the Hoof Smart Bath solution. We also acknowledge Odd Ivar Lekang at the Norwegian University of Life Sciences (Oslo, Norway) for the analyses of the samples from the water footbath, as well as veterinarian and senior information and com- munication technology consultant Kjetil Olsen at the Norwegian School of Veterinary Science (Oslo, Norway) for his support with respect to the video monitoring in trial 4. Access to data records from the farm was given by the Norwegian Dairy Herd Recording System (NDHRS, Hamar, Norway) in agreement number $1 / 2012$. The study was funded by Animalia Meat and Poultry Research Centre (Oslo, Norway), TINE Norwegian Dairies BA (Oslo, Norway), the Research Council of Norway (Oslo, Norway), the Agricultural Agreement Research Fund, and the Foundation for Research Levy on Agricultural Products (Oslo, Norway).

\section{REFERENCES}

Andersson, E., and A. M. Hansen. 2008. Contagious claw diseases in dairy cows, when transferring from a tie stall to a free stall. MS Degree Project. Norwegian School of Veterinary Science, Oslo, Norway.

Andersson, L., and K. Lundström. 1981. The influence of breed, age, body weight and season on digital diseases and hoof size in dairy cows. Zentralbl. Veterinärmed. A 28:141-151.

Bergsten, C., and A. H. Herlin. 1996. Sole haemorrhages and heel horn erosion in dairy cows: The influence of housing system on their prevalence and severity. Acta Vet. Scand. 37:395-408.

Bergsten, C., J. Hultgren, and A. Hillström. 2007. Using copper sulphate, peracetic acid, or a combination of both in foot bath for the control of digital dermatitis and heel horn erosion in dairy cows. Page 96 in Proc. XIII Int. Soc. Anim. Hyg., Tartu, Estonia. A. Aland, ed. The Estonian University of Life Sciences, Tartu, Estonia.

Berry, S. L. 2001. Diseases of the digital soft tissues. Vet. Clin. North Am. Food Anim. Pract. 17:129-142.

Bertelsen, C. 2010. Automatiske klovvaskere. FarmTest nr. 73. Videncentret for landbrug kvæg. Accessed June 25, 2013. https://www.landbrugsinfo.dk/Tvaerfaglige-emner/FarmTest/ Sider/FT-73_Klovvaskere_web.pdf?download=true.

Blowey, R., and N. Chesterton. 2012. Effect of footbath width on fecal contamination by cattle. Vet. Rec. 170:628 http://dx.doi. org/10.1136/vr.e4100.

Borderas, T. F., B. Pawluczuk, A. M. de Passillé, and J. Rushen. 2004 Claw hardness of dairy cows: Relationship to water content and claw lesions. J. Dairy Sci. 87:2085-2093.

Bruijnis, M. R., B. Beerda, H. Hogeveen, and E. N. Stassen. 2012. Assessing the welfare impact of foot disorders in dairy cattle by a modeling approach. Animal 6:962-970.

Bruijnis, M. R., H. Hogeveen, and E. N. Stassen. 2010. Assessing economic consequences of foot disorders in dairy cattle using a dynamic stochastic simulation model. J. Dairy Sci. 93:2419-2432.

Collins, J. J., and G. A. Lineker. 2004. A review and meta-analysis of formaldehyde exposure and leukemia. Regul. Toxicol. Pharmacol. 40:81-91.

Cook, N. B., J. Rieman, A. Gomez, and K. Burgi. 2012. Observations on the design and use of footbaths for the control of infectious hoof disease in dairy cattle. Vet. J. 193:669-673. http://dx.doi. org/10.1016/j.tvjl.2012.06.051.

Döpfer, D., A. Gomez, K. Burgi, R. Trinco, J. Pudwill, J. Wiedmeyer, A. F. Dusick, N. Bernadoni, K. M. Pertzborn, C. R. Chatwick, J. Morelli, J. Fernandes, and N. B. Cook. 2011a. Long-term evaluation of footbath agents for the prevention of infectious claw disease in dairy cattle. Page 2 in Proc. 16th Symp. 8th Conf. Lameness Rumin., Rotorua, New Zealand.

Döpfer, D., A. Koopmans, F. A. Meijer, I. Szakáll, Y. H. Schukken, W. Klee, R. B. Bosma, J. L. Cornelisse, A. J. A. M. van Asten, and A. A. H. M. ter Huurne. 1997. Histological and bacteriological evaluation of digital dermatitis in cattle, with special reference to spirochaetes and Campylobacter faecalis. Vet. Rec. 140:620-623. 
Döpfer, D., M. Lopez-Benavides, M. Buchalova, C. Mateus, N. B. Cook, A. F. Dusick, T. C. Hemling, M. Socha, D. Read, and A. Gomez. 2011b. Clinical, histopathological, and microbial cure of acute digital dermatitis lesions and the influence of topical treatments upon cure. Page 25 in Proc. 16th Symp. 8th Conf. Lameness Rumin., Rotorua, New Zealand.

Evans, N. J., J. M. Brown, I. Demirkan, R. D. Murray, W. D. Vink, R. W. Blowey, C. A. Hart, and S. D. Carter. 2008. Three unique groups of spirochetes isolated from digital dermatitis lesions in UK cattle. Vet. Microbiol. 130:141-150.

Fiedler, A., B. Haidn, S. Maier, and J. Maierl. 2013. Evaluation of a claw hygiene system concerning its cleaning effect, the cow traffic and the quality of the washing water. Tierärztl. Prax. Ausg. G Grosstiere Nutztiere 41:20-30.

Fjeldaas, T., Å. M. Sogstad, and O. Østerås. 2011. Locomotion and claw disorders in Norwegian dairy cows housed in freestalls with slatted concrete, solid concrete, or rubber flooring in the alleys. J. Dairy Sci. 94:1243-1255.

Galindo, F., and D. M. Broom. 2002. Effects of lameness on social and individual behavior of dairy cows. J. Appl. Anim. Welf. Sci. 5:193-201.

Greenough, P. R. 2007. Bovine Laminitis and Lameness. A Hands-On Approach. W. B. Saunders Co., Edinburgh, UK.

Gregory, N., L. Craggs, N. Hobson, and C. Krogh. 2006. Softening of cattle hoof soles and swelling of heel horn by environmental agents. Food Chem. Toxicol. 44:1223-1227.

Holzhauer, M., C. J. Bartels, C. Bergsten, M. M. J. van Riet, K. Frankena, and T. J. G. M. Lam. 2012. The effect of an acidified, ionized copper sulphate solution on digital dermatitis in dairy cows. Vet. J. 193:659-663.

Holzhauer, M., C. J. Bartels, M. van Barneveld, C. Vulders, and T. Lam. 2011. Curative effect of topical treatment of digital dermatitis with a gel containing activated copper and zinc chelate. Vet. Rec. 169:555 http://dx.doi.org/10.1136/vr.d5513.

Hultgren, J., and C. Bergsten. 2001. Effects of a rubber-slatted flooring system on cleanliness and foot health in tied dairy cows. Prev. Vet. Med. 52:75-89.

IARC (International Agency for Research on Cancer). 2006. Formaldehyde, 2-butoxyethanol and 1-tert-butoxypropan-2-ol. IARC Monographs on the Evaluation of Carcinogenic Risks to Humans. Vol. 88. IARC, Lyon, France.

Jorritsma, R., B. J. Lansink, and D. Döpfer. 2007. Vergelijking van twee soorten voetbaden op het voorkomen van de dermatitis digitalis en dermatitis interdigitalis op een melkveebedrijf. Tijdschr. Diergeneeskd. 132:950-952.

Knappe-Poindecker, M., M. Gilhuus, T. K. Jensen, K. Klitgaard, R. B. Larssen, and T. Fjeldaas. 2013. Interdigital dermatitis, heel horn erosion, and digital dermatitis in 14 Norwegian dairy herds. J. Dairy Sci. 96:7617-7629.

Laing, E. A., and J. R. Egerton. 1978. The occurrence, prevalence and transmission of Bacteroides nodosus in cattle. Res. Vet. Sci. 24:300-304.

Laven, R. A., and H. Hunt. 2002. Evaluation of copper sulphate, formalin and peracetic acid in footbaths for the treatment of digital dermatitis in cattle. Vet. Rec. 151:144-146.

Laven, R. A., and D. N. Logue. 2006. Treatment strategies for digital dermatitis for the UK. Vet. J. 171:79-88.

Manske, T., J. Hultgren, and C. Bergsten. 2002a. Topical treatment of digital dermatitis associated with severe heel-horn erosion in a Swedish dairy herd. Prev. Vet. Med. 53:215-231.
Manske, T., J. Hultgren, and C. Bergsten. 2002b. The effect of claw trimming on the hoof health of Swedish dairy cattle. Prev. Vet. Med. 54:113-129.

Manske, T., J. Hultgren, and C. Bergsten. 2002c. Prevalence and interrelationships of hoof lesions and lameness in Swedish dairy cows. Prev. Vet. Med. 54:247-263.

Mitchell, G. B., and J. M. Law. 1984. Formaldehyde poisoning in cattle. Vet. Rec. 115:283-284.

Nielsen, B. H., P. T. Thomsen, L. E. Green, and J. Kaler. 2012. A study of the dynamics of digital dermatitis in 742 lactating dairy cows. Prev. Vet. Med. 104:44-52.

Norwegian Ministry of the Environment. 1981. Act of 13 March 1981 No. 6 Concerning Protection Against Pollution and Concerning Waste. Accessed Jun. 15, 2013. http://www.regjeringen.no/en/ doc/Laws/Acts/Pollution-Control-Act.html?id=171893.

Relun, A., A. Lehebel, M. Bruggink, N. Bareille, and R. Guatteo. 2013. Estimation of the relative impact of treatment and herd management practices on prevention of digital dermatitis in French dairy herds. Prev. Vet. Med. 110:558-562.

Salam, D. and M. El-Fadel. 2008. Mobility and availability of copper in agricultural soils irrigated from water treated with copper sulfate algaecide. Water Air Soil Pollut. 195:3-13.

Sogstad, A. M., T. Fjeldaas, O. Østerås, and K. P. Forshell. 2005. Prevalence of claw lesions in Norwegian dairy cattle housed in tie stalls and free stalls. Prev. Vet. Med. 70:191-209.

Sogstad, A. M., O. Østerås, and T. Fjeldaas. 2006. Bovine claw and limb disorders related to reproductive performance and production diseases. J. Dairy Sci. 89:2519-2528.

Somers, J. G. C. J., K. Frankena, E. N. Noordhuizen-Stassen, and J. H. M. Metz. 2005. Risk factors for interdigital dermatitis and heel erosion in dairy cows kept in cubicle houses in the Netherlands. Prev. Vet. Med. 71:23-34.

Speijers, M. H., L. G. Baird, G. A. Finney, J. McBride, D. J. Kilpatrick, D. N. Logue, and N. E. O'Connell. 2010. Effectiveness of different footbath solutions in the treatment of digital dermatitis in dairy cows. J. Dairy Sci. 93:5782-5791.

Sprecher, D. J., D. E. Hostetler, and J. B. Kaneene. 1997. A lameness scoring system that uses posture and gait to predict dairy cattle reproductive performance. Theriogenology 47:1179-1187.

Telezhenko, E., C. Bergsten, M. Magnusson, and C. Nilsson. 2009 Effect of different flooring on claw conformation of dairy cows. J. Dairy Sci. 92:2625-2633. http://dx.doi.org/10.3168/jds.20081798.

Thomsen, P. T., A. K. Ersbøll, and J. T. Sørensen. 2012. Short communication: Automatic washing of hooves can help control digital dermatitis in dairy cows. J. Dairy Sci. 95:7195-7199. http:// dx.doi.org/10.3168/jds.2011-5171.

Thomsen, P. T., J. T. Sørensen, and A. K. Ersbøll. 2008. Evaluation of three commercial hoof-care products used in footbaths in Danish dairy herds. J. Dairy Sci. 91:1361-1365.

Trent, A. M., and K. A. Redic-Kill. 1997. Clinical pharmacology. Pages 57-70 in Lameness in Cattle. P. R. Greenough and A. D. Weaver, ed. Saunders, London, UK.

Walker, R. L., D. H. Read, K. J. Loretz, and R. W. Nordhausen. 1995. Spirochetes isolated from dairy cattle with papillomatous digital dermatitis and interdigital dermatitis. Vet. Microbiol. 47:343-355. 